University of Windsor

Scholarship at UWindsor

2012

\title{
Low Levels of Extra-Pair Paternity in a Neotropical Duetting Songbird, the Rufous-and-White Wren (Thryothorus rufalbus)
}

\author{
Sarah B. Douglas \\ University of Windsor \\ Daniel D. Heath \\ University of Windsor \\ Daniel J. Mennill \\ University of Windsor
}

Follow this and additional works at: https://scholar.uwindsor.ca/glierpub

Part of the Biochemistry, Biophysics, and Structural Biology Commons, and the Physical Sciences and Mathematics Commons

\section{Recommended Citation}

Douglas, Sarah B.; Heath, Daniel D.; and Mennill, Daniel J.. (2012). Low Levels of Extra-Pair Paternity in a Neotropical Duetting Songbird, the Rufous-and-White Wren (Thryothorus rufalbus). Condor, 114 (2), 393-400.

https://scholar.uwindsor.ca/glierpub/33

This Article is brought to you for free and open access by the Great Lakes Institute for Environmental Research at Scholarship at UWindsor. It has been accepted for inclusion in Great Lakes Institute for Environmental Research Publications by an authorized administrator of Scholarship at UWindsor. For more information, please contact scholarship@uwindsor.ca. 


\title{
Low Levels of Extra-Pair Paternity in a Neotropical Duetting Songbird, the Rufous-and-White Wren (Thryothorus rufalbus)
}

\author{
Author(s): Sarah B. Douglas, Daniel D. Heath and Daniel J. Mennill
}

Source: The Condor, 114(2):393-400.

Published By: Cooper Ornithological Society

URL: http://www.bioone.org/doi/full/10.1525/cond.2012.110028

BioOne (www.bioone.org) is a nonprofit, online aggregation of core research in the biological, ecological, and environmental sciences. BioOne provides a sustainable online platform for over 170 journals and books published by nonprofit societies, associations, museums, institutions, and presses.

Your use of this PDF, the BioOne Web site, and all posted and associated content indicates your acceptance of BioOne's Terms of Use, available at www.bioone.org/page/terms_of_use.

Usage of BioOne content is strictly limited to personal, educational, and non-commercial use. Commercial inquiries or rights and permissions requests should be directed to the individual publisher as copyright holder. 


\title{
LOW LEVELS OF EXTRA-PAIR PATERNITY IN A NEOTROPICAL DUETTING SONGBIRD, THE RUFOUS-AND-WHITE WREN (THRYOTHORUS RUFALBUS)
}

\author{
Sarah B. Douglas ${ }^{1}$, Daniel D. Heath ${ }^{2}$, and Daniel J. Mennill ${ }^{1,3}$ \\ ${ }^{1}$ Department of Biological Sciences, University of Windsor, Windsor, Ontario, Canada \\ ${ }^{2}$ Department of Biological Sciences and Great Lakes Institute of Environmental Research, University of Windsor, \\ Windsor, Ontario, Canada
}

\begin{abstract}
Molecular analyses have confirmed that the majority of socially monogamous birds follow a genetically promiscuous reproductive strategy. Most such studies, however, have addressed species of the North Temperate Zone; tropical species are grossly underrepresented, although most of Earth's biodiversity is concentrated in the tropics. In this study, we describe the genetic mating strategy of the Rufous-and-white Wren (Thryothorus rufalbus), a socially monogamous duetting neotropical songbird. Over 8 years of studying a marked population in Costa Rica, we recorded genetic data from 51 broods. Microsatellite analysis of four variable loci revealed that the Rufous-and-white Wren follows a mixed reproductive strategy, where extra-pair young are found in a small minority of broods. Three of 158 nestlings $(2 \%)$ were the result of extra-pair fertilizations; three of the 51 broods $(6 \%)$ contained a nestling with alleles mismatched to its social father. We assigned paternity of two of the extra-pair nestlings to males in territories adjacent to the cuckolded males. During behavioral observations, we observed within-pair copulations rarely and extra-pair copulations never. The rate of extra-pair paternity we report here is lower than the average reported for socially monogamous birds in the North Temperate Zone but comparable to rates in three closely related tropical wrens. Rufous-and-white Wrens are renowned for their coordinated vocal duets. We compared rates of extra-pair paternity among socially monogamous tropical birds, contrasting four duetting species against twelve nonduetting species and found lower levels of extra-pair paternity in the former group, suggesting that duetting and low levels of extra-pair paternity are related.
\end{abstract}

Key words: extra-pair paternity, mating systems, Rufous-and-white Wren, Thryothorus rufalbus, tropical birds, vocal duets.

\section{Bajos Niveles de Paternidad Extra-Pareja en un Ave Neotropical Canora que Emite Duetos, Thryothorus rufalbus}

Resumen. Los análisis moleculares han confirmado que la mayoría de las aves monógamas sociales siguen una estrategia reproductiva genéticamente promiscua. La mayoría de estos estudios, sin embrago, se han enfocado en especies de la Zona Templada Norte; las especies tropicales están extremadamente sub-representadas, aunque la mayoría de la diversidad en la Tierra está concentrada en los trópicos. En este estudio, describimos la estrategia genética de apareamiento de Thryothorus rufalbus, un ave neotropical canora socialmente monógama que emite duetos. A lo largo de 8 años de estudio de una población de individuos marcados en Costa Rica, registramos los datos genéticos de 51 nidadas. Los análisis de microsatélites de cuatro loci variables revelaron que T. rufalbus sigue una estructura reproductiva mixta, donde los jóvenes provenientes de relaciones extra-pareja representan una pequeña minoría de las nidadas. Tres de los 158 pichones (2\%) fueron el resultado de fertilizaciones extra-pareja; tres de las 51 nidadas $(6 \%)$ albergaron un pichón con alelos no coincidentes con su padre social. Asignamos la paternidad de dos pichones extra-pareja a machos de territorios adyacentes a los machos "engañados." Durante las observaciones de comportamiento, registramos raramente cópulas intra-pareja y nunca extra-pareja. La tasa de paternidad extra-pareja que reportamos aquí es menor que el promedio reportado para aves sociales monógamas de la Zona Templada Norte pero comparable a las tasas en tres especies tropicales cercanamente relacionadas en la familia Troglodytidae. Los individuos de T. rufalbus son renombrados por sus duetos vocales coordinados. Comparamos las tasas de paternidad extra-pareja entre aves tropicales socialmente monógamas, contrastando cuatro especies que emiten duetos contra doce especies que no emiten duetos, encontrando bajos niveles de paternidad extra-pareja en el primer grupo, sugiriendo que la producción de duetos y los bajos niveles de paternidad extra-pareja están relacionados.

Manuscript received 15 February 2011; accepted 13 September 2011.

${ }^{3}$ E-mail: dmennill@uwindsor.ca

The Condor, Vol. 114, Number 2, pages 393-400. ISSN 0010-5422, electronic ISSN 1938-5422. (c) 2012 by The Cooper Ornithological Society. All rights reserved. Please direct all requests for permission to photocopy or reproduce article content through the University of California Press's Rights and Permissions website, http://www.ucpressjournals.com/ reprintInfo.asp. DOI: 10.1525/cond.2012.110028 


\section{INTRODUCTION}

Birds have played a pivotal role as model systems for studies of sexual selection (Andersson 1994, Birkhead and Møller 1998). Since the introduction of molecular techniques for the study of avian mating systems over three decades ago, researchers have gained much insight into female mate choice and reproductive strategies. Studies using genetic markers have revealed that although $90 \%$ of bird species are socially monogamous, fewer than $14 \%$ of species surveyed are genetically monogamous, as a result of females following mixed strategies by copulating with males other than their social partner (reviewed in Griffith et al. 2002). There is much debate over the relative importance of various ecological, life-history, and behavioral factors that appear to influence interspecific variation in rates of extra-pair paternity (Westneat and Stewart 2003). The majority of hypotheses proposed to explain this variation are based on genetic studies of species of the North Temperate Zone; species resident in the South Temperate and tropical zones are grossly underrepresented in spite of the majority of bird species being concentrated in the tropics (Macedo et al. 2008, Stutchbury and Morton 2001, Tori et al. 2008). Without an understanding of extra-pair paternity in tropical species, we cannot draw broad conclusions about extra-pair paternity or its role in sexual selection among socially monogamous birds (Macedo et al. 2008).

Although data are limited, genetic studies of 15 species to date suggest that extra-pair paternity rates among socially monogamous tropical birds vary markedly and may be comparable to rates seen in temperate-zone birds (reviewed in Macedo et al. 2008; see also Krueger et al. 2008, Kingma et al. 2010, Cramer et al. 2011). Although conclusions have limited scope with such an extreme minority of tropical species sampled, the accumulated data suggest that an average of $17 \%$ of young result from extra-pair fertilizations, and $24 \%$ of broods contain extra-pair young (averages across all of the above references). These rates are comparable to the levels of extra-pair paternity seen across all socially monogamous birds (Griffith et al. 2002, Macedo et al. 2008).

Many tropical bird species produce vocal duets. These complex acoustic displays occur when two birds, usually the male and female of a mated pair, combine their vocalizations in a coordinated fashion (Farabaugh 1982, Hall 2004, 2009, Douglas and Mennill 2010). Few studies have determined the genetic mating strategy of tropical duetting species, so it is not yet possible to assess the relationship between duetting behavior and genetic mating strategy accurately. To date, rates of extra-pair paternity have been investigated in three socially monogamous duetting tropical birds (the Dusky Antbird, Cercomacra tyrannina, Fleischer et al. 1997; Purplecrowned Fairy-wren, Malurus coronatus, Kingma et al. 2010; and Buff-breasted Wren, Thryothorus leucotis, Gill et al. 2005); extra-pair paternity is rare in all three species ( 0 to $4 \%$ of young; 0 to $6 \%$ of broods). Although many more studies are needed, if extra-pair paternity is consistently lower among duetting birds than among nonduetting birds, duetting and its associated traits may provide insight into interspecific variation in extra-pair paternity. Indeed, duets have been argued to play a role in paternity guarding (Sonnenschein and Reyer 1983), although it is difficult to predict whether duetting should result in higher or lower rates of extra-pair paternity (see Hall 2004:422). If duets signal commitment to a partnership (Wickler 1980) or help synchronize breeding (Dilger 1953), we might expect lower incidence of extra-pair paternity in duetting species (reviewed in Hall 2004).

In this study, we describe the genetic mating strategy of the Rufous-and-white Wren (Thryothorus rufalbus), a duetting neotropical songbird with socially monogamous mating behavior. In this species, one male and one female defend a territory together (Mennill 2006, Osmun and Mennill 2011) and build a globular nest (Mennill and Vehrencamp 2008). Males assist with nest building and nestling provisioning, but females alone are responsible for incubation (Topp and Mennill 2008). Over 8 years of studying a population of marked individuals in northwestern Costa Rica, we observed 176 breeding pairs and took genetic samples from 51 broods, making this one of the more comprehensive long-term studies of paternity in a socially monogamous tropical bird to date.

\section{METHODS}

\section{STUDY POPULATION AND OBSERVATIONS}

The Rufous-and-white Wren is a year-round resident of the mature humid and late-succession forests of the north $\mathrm{Pa}$ cific slope of Costa Rica. We studied a population in Sector Santa Rosa of the Guanacaste Conservation Area $\left(10^{\circ} 40^{\prime} \mathrm{N}\right.$, $\left.85^{\circ} 30^{\prime} \mathrm{W}\right)$. We observed birds daily throughout the breeding season between approximately April and July of 2003 to 2010. The study population included $22.0 \pm 1.5$ pairs per year (average \pm SE; range 17-31 pairs per year). We captured adult birds with mist nets, recorded standard measurements, and assigned each individual a unique combination of three colored plastic bands and one numbered aluminum band. We obtained blood samples from adults through venipuncture of the brachial vein (35-75 $\mu \mathrm{L}$ per bird). We determined the sex of each adult bird by observing singing and incubation behaviors (structural differences in songs distinguish the sexes; incubation is limited to females; Mennill and Vehrencamp 2005, Topp and Mennill 2008).

For each pair, we defined the social father as the male who sang on the nesting territory, performed vocal duets with the social mother, and assisted with nest building. We defined the social mother as the female who sang on the nesting territory, assisted with nest building, provisioned nestlings, and incubated eggs. Among 176 breeding pairs monitored between 2003 and 2010, all birds except one bred as monogamous pairs. In 2009 a case of polygamy entailed two nearby females 
pairing with a single male and breeding simultaneously in different nests at opposite ends of the male's territory. Each of these females had paired with this male as a monogamous partner, in turn, during the two preceding years. We consider this behavior atypical and suggest that the Rufous-and-white Wren should be considered socially monogamous.

We monitored the reproductive activities of all pairs by watching the behavior of the parents or by checking the nest for eggs. When nestlings were 3 to 6 days old, we used venipuncture to obtain a 10 - to $25-\mu \mathrm{L}$ blood sample from the tibio-tarsal vessels (less than the amount recommended for nonharmful sampling; Gaunt and Oring 1997). Blood was preserved in $\sim 1.5 \mathrm{~mL}$ of Queen's lysis buffer (Seutin et al. 1991). Predation and nest destruction were severe, with $>65 \%$ of the monitored nests being depredated each year. Most nests were destroyed by white-faced capuchin monkeys (Cebus capucinus), White-throated Magpie-Jays (Calocitta formosa), or snakes before the nestlings could be sampled.

We looked for copulations, both within-pair and extrapair, over 8 years of field study. These observations were opportunistic and limited because Rufous-and-white Wrens are secretive and difficult to observe (Mennill and Vehrencamp 2008). As part of a long-term study of the birds' vocal behavior, one to three field researchers recorded and observed birds daily for approximately 3 months of every year between 2003 and 2010; this resulted in approximately 800 observer-hours per year for possible detection of copulations while researchers followed pairs to record them.

\section{GENETIC ANALYSIS OF PATERNITY}

We assessed the paternity of all sampled nestlings with four microsatellite loci (ThPl-14, ThPl-22, ThPl-26, and ThPl-30) that were originally identified in the Banded Wren (Thryothorus pleurostictus; Brar et al. 2007). We isolated Rufousand-white Wren DNA by a plate-based extraction method (we added $\sim 10-15 \mu \mathrm{L}$ of whole blood sample to $160 \mu \mathrm{L}$ of digestion buffer and $5 \mu \mathrm{L}$ of $20 \mathrm{mM}$ proteinase $\mathrm{K}$ ). Plates were incubated at $37^{\circ} \mathrm{C}$ for a minimum of $6 \mathrm{hr}$, and DNA was extracted per Elphinstone et al. (2003).

To assign paternity we ran polymerase chain reactions (PCR) by following the cycling profile outlined in Brar et al. (2007): 1 cycle at $94{ }^{\circ} \mathrm{C}$ for $2 \mathrm{~min}$, followed by 30 cycles of $30 \mathrm{sec}$ at $94{ }^{\circ} \mathrm{C}, 30 \mathrm{sec}$ at $58^{\circ} \mathrm{C}$, and $30 \mathrm{sec}$ at $72{ }^{\circ} \mathrm{C}$, followed by a final extension cycle of $1 \mathrm{~min}$ at $72{ }^{\circ} \mathrm{C}$. In our sample, the annealing temperature of $58{ }^{\circ} \mathrm{C}$ recommended by Brar et al. (2007) for ThPl-30 produced a high frequency of large-allele dropout; we eliminated this problem by decreasing the annealing temperature to $50{ }^{\circ} \mathrm{C}$ for all ThPl-30 reactions. For all samples, we amplified microsatellite loci with $0.5 \mu \mathrm{L}$ of genomic DNA in $12.5-\mu \mathrm{L}$ reactions. PCRs contained $2.4 \mathrm{mM}$ $\mathrm{MgCl}_{2}, 192.3 \mu \mathrm{M}$ of each dNTP (Promega), 0.17-0.29 $\mu \mathrm{M}$ each of forward and reverse primers, 0.05 units of Taq polymerase (Amplitaq DNA, Applied Biosystems), $1.25 \mu \mathrm{L}$ each of bovine serum albumin and buffer (Applied Biosystems), and
TABLE 1. Characterization of four microsatellite loci used for paternity analysis in the Rufous-and-white Wren.

\begin{tabular}{|c|c|c|c|c|c|c|}
\hline \multirow[b]{2}{*}{ Locus $^{\mathrm{a}}$} & \multirow{2}{*}{$\begin{array}{l}\text { Annealing } \\
\text { temp }\left({ }^{\circ} \mathrm{C}\right)\end{array}$} & \multirow{2}{*}{$\begin{array}{l}\text { Number } \\
\text { of alleles }\end{array}$} & \multicolumn{2}{|c|}{ Heterozygosity } & \multicolumn{2}{|c|}{$\begin{array}{l}\text { Probability } \\
\text { of exclusion }\end{array}$} \\
\hline & & & Expected & Observed & $P_{\mathrm{ex} 1}$ & $P_{\mathrm{ex} 2}$ \\
\hline ThPl-14 & 58 & 9 & 0.801 & 0.789 & 0.45 & 0.63 \\
\hline ThPl-22 & 58 & 11 & 0.715 & 0.607 & 0.32 & 0.51 \\
\hline ThPl-26 & 58 & 2 & 0.232 & 0.196 & 0.03 & 0.10 \\
\hline ThPl-30 & 50 & 14 & 0.856 & 0.737 & 0.57 & 0.72 \\
\hline
\end{tabular}

a Originally identified in the Banded Wren (Thryothorus pleurostictus) by Brar et al. 2007.

bData based on 56 (ThPl-22, ThPl-26) or 57 (ThPl-14, ThPl-30) adult birds sampled 2003-2010.

cProbability of exclusion when the genotype of one $\left(P_{\text {ex } 1}\right)$ or both $\left(P_{\mathrm{ex} 2}\right)$ parents is known.

$7.45 \mu \mathrm{L}$ of double-distilled water. Forward primers were unlabeled, and reverse primers were modified at the $5^{\prime}$ end by a fluorescent label (IR Dye 700 and IR Dye 800; IDT Primers). To visualize PCR fragments, we ran labeled PCR products on a LICOR 4300 DNA analyzer (version 1.3.8-1, Biosciences) with positive and negative standards. We estimated allele sizes with GENEIMAGR (version 4.05). In all cases, we ran nestlings on gels directly beside their putative parents to minimize inter-gel variability. To minimize observer bias, two independent observers scored allele sizes for all individuals.

Three of the four microsatellite loci were highly variable, with 9 to 14 alleles per locus and expected and observed heterozygosities of $>60.7 \%$ based on samples of 56 (ThPl22) and 57 (ThPl-14 and ThPl-30) adult birds (Table 1). The remaining locus, ThPl-26, was less variable, with only two alleles detected and expected and observed heterozygosities of $>19.6 \%$ (Table 1). Alleles at all four loci appeared to follow Mendelian inheritance, with parental alleles sorting to approximately $50 \%$ of offspring. We calculated allele frequencies and Hardy-Weinberg equilibrium probabilities by using parental DNA with GenAlEx (version 6.4). Locus ThPl26 was in Hardy-Weinberg equilibrium, while the other three deviated (ThPl-14, $P<0.01$; ThPl-22, $P<0.001$; ThPl-30, $P<0.01)$. With all four loci combined, probability of an extrapair nestling being detected was $99.5 \%$ if the mother's genotype was known ( 45 broods), and $97.3 \%$ if the mother's genotype was unknown (6 broods).

We considered offspring to be extra-pair if they had allelic mismatches with their social father at two or more of the four loci. When possible, we assigned parentage of extra-pair young by running nestlings alongside adult males that held territories near the nesting territory (i.e., all sampled males holding territories within $1 \mathrm{~km}$ of the natal nest plus many additional males in the population). We assessed rates of genotyping error by amplifying 25 individuals from 2010 twice, at two polymorphic loci (ThPl-14 and ThPl-30). 
The allele mismatch rate was zero, suggesting that the error rates are low. We are confident that deviations from HardyWeinberg equilibrium in our population reflect not genotyping error but patterns of nonrandom mating (likely arising from restricted dispersal due to limited mature habitat at the study site and the linear arrangement of breeding territories).

\section{EXTRA-PAIR PATERNITY IN DUETTING VERSUS NONDUETTING TROPICAL BIRDS}

We reviewed studies describing the genetic mating strategy of duetting and nonduetting socially monogamous tropical birds (12 species included in Macedo et al. 2008, plus Krueger et al. 2008, Kingma et al. 2010, Cramer et al. 2011, and our study). From each study, we recorded the percentage of offspring resulting from extra-pair fertilizations and the number of broods in which these offspring were detected.

All values are reported as mean $\pm \mathrm{SE}$.

\section{RESULTS}

\section{PATERNITY IN THE RUFOUS-AND-WHITE WREN}

We collected genetic data from 158 Rufous-and-white Wren nestlings in 51 broods between 2003 and 2010. We sampled $7.3 \pm 1.0$ broods per year, except in 2004 , when paternity wasn't sampled. Brood size ranged from 1 to 5 and averaged $3.1 \pm 0.1$.

Microsatellite paternity analysis revealed that Rufousand-white Wrens follow a mixed but predominantly monogamous reproductive strategy; only three of 158 nestlings ( $2 \%)$ were the result of extra-pair fertilizations. Three of the 51 broods sampled (6\%) included one nestling with allelic mismatches to the social father at exactly two of the four loci. We assigned paternity to the social father for the remaining 155 nestlings sampled; all of these nestlings matched their social father at all four loci. All offspring, including those sired by extra-pair males, matched the genotype of the social mother at all four loci.

We assigned paternity for two of the three extra-pair young. Both of these extra-pair nestlings genetically matched an adult male in an adjacent territory at all four loci. The nests of the extra-pair sires and the nests with the extra-pair young were separated by relatively short distances of 25 and $150 \mathrm{~m}$. We were unable to assign paternity of the third extra-pair nestling to any sampled male, including males in neighboring territories. However, an unbanded bachelor male occupied an adjacent territory, and he is a likely candidate for the extrapair sire.

We rarely observed Rufous-and-white Wrens copulate. We observed within-pair copulations on only 10 occasions over 8 years of study (approximately 6400 observer-hours). These copulations were observed early in the morning (07:58 $\pm 29 \mathrm{~min}$; range: 06:15-10:40) and involved brief precopulatory displays. Both birds cocked and wagged their tails back and forth, lowered their wings to the sides of their bodies, fluttered their wings rapidly, and gave short chases while moving from branch to branch prior to copulating. In four of the ten cases, multiple copulations were observed in rapid succession. Bouts of song, including duets, were noted prior to eight of the ten copulations. We never observed extra-pair copulations.

\section{PATERNITY IN DUETTING VERSUS NONDUETTING TROPICAL BIRDS}

We found extra-pair paternity in socially monogamous tropical birds to be lower in duetting species. Extra-pair young have been found in a significantly smaller proportion of broods of duetting than of nonduetting species (Table 2; Mann-Whitney $U=2.3, P=0.02, n=18$ ). Extra-pair young tend to constitute a lower proportion of all young sampled in these studies, although this difference is not statistically significant (Table 2; Mann-Whitney: $U=1.8, P=0.08, n=16$ ).

\section{DISCUSSION}

Rufous-and-white Wrens exhibit low levels of extra-pair paternity. Two percent of all nestlings sampled resulted from extra-pair fertilizations, and $6 \%$ of broods contained a single extra-pair offspring. All nestlings were the genetic offspring of their social mother, indicating that intraspecific brood parasitism is rare or absent in this species. For two of the three extra-pair young, we assigned paternity to a breeding male in a neighboring territory. We could not assign paternity to the third extra-pair young, but we suspect it was sired by an unsampled bachelor male in a neighboring territory. Our results show that Rufousand-white Wrens are socially monogamous but genetically promiscuous, although this promiscuity occurs at a low level.

The rate of extra-pair paternity we found in the Rufousand-white Wren is lower than the average reported across all socially monogamous birds (11.1\% of offspring, $18.7 \%$ of broods; Griffith et al. 2002) and lower than the average reported across all temperate-zone species $(11.3 \%$ of young, $17.6 \%$ of broods; data from Griffith et al. 2002 as presented by Macedo et al. 2008). In the Rufous-and-white Wren, however, this rate is similar to that in other species of Thryothorus, including two neotropical wrens and one temperate-zone wren. In the tropical Buff-breasted Wren, Gill et al. (2005) reported that extra-pair young accounted for $4 \%$ of 53 nestlings and were found in $3 \%$ of 31 broods. In the tropical Banded Wren, Cramer et al. (2011) reported that extra-pair young accounted for $4 \%$ of 156 nestlings and were found in $10 \%$ of 50 broods. In the temperate-zone Carolina Wren (T. ludovicianus), Haggerty et al. (2001) detected no extra-pair young among 84 nestlings in 16 broods. Of these three species, the Banded Wren is most closely related to the Rufous-and-white (Mann et al. 2009). Together, these results suggest that levels of extra-pair paternity in Thryothorus are low. More broadly, 
TABLE 2. Rates of extra-pair paternity in socially monogamous tropical duetting and nonduetting birds.

\begin{tabular}{lccll}
\hline \hline & \multicolumn{2}{c}{ Percent extra-pair paternity } & \\
\cline { 2 - 3 } Species & Young & Broods & & Source \\
\hline Nonduetting & & & \\
Green-rumped Parrotlet (Forpus passerinus) & 8 & 14 & & Melland 2000 \\
Yellow-bellied Elaenia (Elaenia flavogaster) & 4 & 8 & & Stutchbury et al. 2007 \\
Lesser Elaenia (Elaenia chiriquensis) & 37 & 67 & & Stutchbury et al. 2007 \\
Red-backed Fairy-wren (Malurus melanocephalus) & 51 & 63 & & Webster et al. 2008 \\
Mangrove Swallow (Tachycineta albilinea) & 15 & 26 & & Moore et al. 1999 \\
Silvereye (Zosterops lateralis) & 0 & 0 & & Robertson 1996 \\
Banded Wren (Thryothorus pleurostictus) & 4 & 10 & & Cramer et al. 2011 \\
Clay-colored Thrush (Turdus grayi) & 38 & 53 & & Stutchbury et al. 1998 \\
Palila (Loxioides bailleui) & 0 & 0 & & Fleischer et al. 1994 \\
Cherrie's Tanager (Ramphocelus costaricensis) & 49 & 55 & & Krueger et al. 2008 \\
Blue-black Grassquit (Volatinia jacarina) & 50 & 63 & & Carvalho et al. 2006 \\
Common Cactus-Finch (Geospiza scandens) & 8 & 15 & & Petren et al. 1999 \\
Average & $22.0 \pm 6.1$ & $31.2 \pm 7.7$ & \\
Duetting & & & \\
Dusky Antbird (Cercomacra tyrannina) & 0 & 0 & Fleischer et al. 1997 \\
Purple-crowned Fairy-wren (Malurus coronatus) & 4 & 6 & Kingma et al. 2010 \\
Rufous-and-white Wren (Thryothorus rufalbus) & 2 & 6 & this study \\
Buff-breasted Wren (Thryothorus leucotis) & 4 & 3 & Gill et al. 2005 \\
Average & $2.5 \pm 1.0$ & $3.8 \pm 1.4$ & \\
\hline & & & \\
\hline
\end{tabular}

rates of extra-pair paternity appear to be low across most species of wrens that have been studied (reviewed in Cramer et al. 2011). When the results of studies of genetic mating strategies of more temperate-zone and tropical duetting species become available, the behavioral and ecological correlates of this variation in mating strategies will be an important area of study.

Genetic studies of socially monogamous birds suggest that several ecological and behavioral variables are associated with low levels of extra-pair paternity, including low density of a breeding population (e.g., Verboven and Mateman 1997), less synchronized breeding (e.g., Stutchbury and Morton 1995, Morton et al. 1998), increased necessity for male parental care (e.g., Morton et al. 1998, Masello et al. 2002), and duetting (Farabaugh 1982, Hall 2004, 2009). Below we explore each of these variables in relation to the low level of extra-pair paternity we found in the Rufous-and-white Wren.

Low population density could influence rates of extrapair paternity by limiting opportunities to engage in extra-pair copulations. Birds breeding at high densities may encounter the opposite sex more often, presenting increased chances for extra-pair mating (Griffith et al. 2002). Rufous-and-white Wrens defend large territories (mean size $13497 \pm 1043 \mathrm{~m}^{2}$; Mennill and Vehrencamp 2008). These territories are arranged linearly or in small clusters where neighbors are often separated by sizable undefended spaces (Mennill and Vehrencamp 2008, Osmun and Mennill 2011), which may limit encounters with potential extra-pair mates. Nest location relative to a neighbor's nest may facilitate extra-pair copulations. The nest of one extra-pair sire we identified was located only $25 \mathrm{~m}$ from the nest containing his genetic offspring, which is much less than the average distance between nests in the population (average unoccupied distance between two neighboring territories is $103.0 \pm$ $18.2 \mathrm{~m}$; Mennill and Vehrencamp 2008). Nest location within a territory is known to influence patterns of extra-pair paternity in a temperate-zone songbird, the Black-capped Chickadee (Poecile atricapillus; Mennill et al. 2004). Our results suggest that nest location may influence extra-pair matings in tropical songbirds similarly.

Stutchbury and Morton (1995) suggested that synchrony of breeding increases extra-pair paternity, although Weatherhead and Yezerinac (1998) and Griffith et al. (2002) suggested the contrary. Birds in our study population initiate their first clutch at the onset of the rainy season with high synchrony (Topp and Mennill 2008). Attempts to renest following nest predation reduce synchrony later in the season, although we have not sampled paternity later in the season. In spite of the highly synchronized breeding of our study population at the time we sampled nestlings, the observed incidence of extrapair paternity is low. Cramer et al. (2011) found the same pattern in a study of paternity and breeding synchrony in the Banded Wren at the same site. We conclude that the low level of extra-pair paternity in the Rufous-and-white Wren does not provide support for the breeding-synchrony hypothesis.

In some birds, rates of extra-pair paternity are related to the degree that male parental care is required for rearing of young (Mulder et al. 1994, Birkhead and Møller 1996, Gowaty 
1996). Females might seek extra-pair copulations when they can raise young with little investment from a male and may be able to risk the cost of reduced male parental care (Griffith et al. 2002). In the Rufous-and-white Wren, both males and females contribute substantially to parental care. Both sexes participate in nest building and both sexes provision nestlings, although females invest more than males in nestling provisioning (Douglas 2011). Our observations suggest that males are also involved in post-fledging care of young, at which point the female may initiate a second clutch. Given that males appear to play an integral role in raising young, it is possible that risks associated with extra-pair copulation (e.g., reduced male parental care) outweigh potential benefits and thus promote low levels of extra-pair paternity. The idea that males are sensitive to their partner's extra-pair mating behavior, however, has not received strong empirical support (e.g., Dickinson 2003, Dijk et al. 2010).

Vocal duetting may correlate with low levels of extra-pair paternity (Farabaugh 1982). Both male and female Rufousand-white Wrens possess a repertoire of song types that they may sing as solos or combine into coordinated antiphonal and polyphonal duets (Mennill and Vehrencamp 2005). We are aware of only three other studies of paternity in socially monogamous tropical duetting species, and rates appear uniformly low (Table 2). Our comparison of extra-pair paternity in tropical duetting and nonduetting species shows that duetting birds have lower rates of extra-pair paternity. This comparison has limited scope because data are available for only 16 socially monogamous tropical species, and our comparison does not control for the effects of phylogeny. Nevertheless, our comparison includes species from diverse taxonomic groups, and some genera are represented in both the duetting and nonduetting categories. Many duetting birds share features apparently common among species with low extra-pair paternity (Farabaugh 1982). For example, year-round territoriality, long-term partnerships, and low adult mortality are traits that may select for genetic monogamy (Griffith et al. 2002). Further studies describing the genetic mating strategy of both duetting and nonduetting tropical birds will elucidate which traits are most important in influencing extra-pair paternity.

One hypothesis proposed for the function of duets is that these coordinated displays act as an acoustic paternity guard, where males protect their paternity by responding to their partner's songs and thereby repel rival males seeking copulations (Sonnenschein and Reyer 1983). Under this hypothesis, males' response rates to their partner's songs should be highest while she is fertile (Sonnenschein and Reyer 1983, Hall 2004), a pattern detected in a previous study of this population (Topp and Mennill 2008). Given that our genetic analyses revealed that the vast majority of pairs are genetically monogamous, perhaps vocal duets function successfully as a paternity guard in this species. Alternatively, perhaps extra-pair paternity is rare for reasons independent of duetting, and the male's heightened responsiveness when the female is fertile period serves other functions, such as guarding partnerships rather than paternity. Future research on partnership lengths and behaviors associated with divorce may help to distinguish these alternatives and offer additional insight into the function of duets.

Although duetting birds are most numerous in the tropics, some species of socially monogamous temperate-zone birds perform duets (Farabaugh 1982, Benedict 2008a). The incidence of extra-pair paternity in these species varies from zero (e.g., Eastern Screech-Owl, Otus asio; Lawless et al. 1997) to moderate (e.g., Magpie-lark, Grallina cyanoleuca: $3 \%$ of young, $6 \%$ of broods; Hall and Magrath 2000) to high (e.g., California Towhee, Melozone crissalis: $26 \%$ of young, $42 \%$ of broods; Benedict 2008b). It is yet unclear whether duets have evolved in temperate-zone and tropical birds for the same reasons, and careful quantification of the incidence of duetting combined with genetic analyses of mating systems will be important for understanding the link between duetting and reproduction.

In conclusion, our 8-year study reveals a low level of extrapair paternity in the neotropical Rufous-and-white Wren. Further studies of the genetic mating strategies of temperate-zone and tropical wrens would enable phylogenetic studies that may help clarify ecological and behavioral factors influencing rates of extra-pair paternity across closely related species. More studies of the genetic mating systems of tropical species are needed for an understanding of the role that extra-pair paternity plays in birds outside of north temperate ecosystems.

\section{ACKNOWLEDGMENTS}

For collecting genetic data that contributed to this study we thank N. Barker and S. Topp. For field assistance we thank P. Bitton, D. Bradley, C. Calaustro, V. Connolly, S. Doucet, B. Douglas, A. Henkel, J. Koloff, D. Maynard, D. Moseley, J. Mouland, and A. Osmun. For logistical support in the field we thank the staff of the Guanacaste Conservation Area, particularly R. Blanco. For guidance and assistance with molecular work we thank C. Beneteau and R. Hepburn as well as M. Liu and H. Mays. For helpful comments on the manuscript we thank two anonymous reviewers. For funding we thank the Natural Sciences and Engineering Research Council of Canada (NSERC), the National Geographic Society, Canada's Foundation for Innovation (CFI), the Ontario government, the Society for Canadian Ornithologists, and the Association of Universities and Colleges of Canada.

\section{LITERATURE CITED}

Andersson, M. B. 1994. Sexual selection. Princeton University Press, Princeton, NJ.

BENEDICT, L. 2008a. Occurrence and life history correlates of vocal duetting in North American passerines. Journal of Avian Biology 39:57-65.

BENEDICT, L. 2008b. Unusually high levels of extrapair paternity in a duetting songbird with long-term pair bonds. Behavioral Ecology and Sociobiology 62:983-988.

Birkhead, T. R., AND A. P. MøLler. 1998. Sperm competition and sexual selection. Academic Press, San Diego.

Brar, R. K., L. A. Schoenle, L. M. Stenzler, M. L. Halls, S. L. VEHRENCAMP, AND I. J. LOVETTE. 2007. Eleven microsatellite loci 
isolated from the Banded Wren (Thryothorus pleurostictus). Molecular Ecology Notes 7:69-71.

Carvalho, C. B. V., R. H. Macedo, and J. A. Graves. 2006. Breeding strategies of a socially monogamous neotropical passerine: extra-pair fertilizations, behavior, and morphology. Condor 108:579-590.

Cramer, E. R. A., M. L. Hall, S. R. DeKoort, I. J. Lovette, and S. L. VeHRENCAMP. 2011. Infrequent extra-pair paternity in the Banded Wren, a synchronously breeding tropical passerine. Condor 113:637-645.

DiCKInSON, J. L. 2003. Male share of provisioning is not influenced by actual or apparent loss of paternity in Western Bluebirds. Behavioral Ecology 14:360-366.

Dijk, R., L. Mescaros, M. Velde, T. Szekely, A. Pogany, J. SZABAD, AND J. Komdeur. 2010. Nest desertion is not predicted by cuckoldry in the Eurasian Penduline Tit. Behavioral Ecology and Sociobiology 64:1425-1435.

Dilger, W. C. 1953. Duetting in the Crimson-breasted Barbet. Condor 55:220-221.

Douglas, S. B., AND D. J. MenniLl. 2010. A review of acoustic playback techniques for studying avian vocal duets. Journal of Field Ornithology 81:115-129.

Douglas, S. B. 2011. The vocal behaviour and reproductive strategies of a neotropical duetting wren. M.Sc. thesis. University of Windsor, Windsor, Ontario.

FARABAUGH, S. M. 1982. The ecological and social significance of duetting, p. 85-124. In D. E. Kroodsma and E. H. Miller [EDS.], Ecology and evolution of acoustic communication in birds. Academic Press, New York.

Fleischer, R. C., C. L. Tarr, and T. K. Pratt. 1994. Genetic structure and mating system in the Palila, an endangered Hawaiian honeycreeper, as assessed by DNA fingerprinting. Molecular Ecology 3:383-392.

Elphinstone, M. S., G. N. Hinten, M. J. Anderson, And C. J. Nock. 2003. An inexpensive and high thoroughput procedure to extract and purify total genomic DNA for population studies. Molecular Ecology Notes 3:317-320.

Fleischer, R. C., C. L. TARr, E. S. Morton, A. SAngmeister, and K. C. Derrickson. 1997. Mating system of the Dusky Antbird, a tropical passerine, as assessed by DNA fingerprinting. Condor 99:512-514.

Gaunt, A. S., AND L. W. Oring. 1997. Guidelines to the use of wild birds in research. Ornithological Council, Washington, DC.

Gill, S. A., M. J. Vonhof, J. M. Stutchbury, E. S. Morton, And J. S. QuinN. 2005. No evidence for acoustic mate-guarding in duetting Buff-breasted Wrens (Thryothorus leucotis). Behavioral Ecology and Sociobiology 57:557-565.

Gowaty, P. A. 1996. Battle of the sexes and origins of monogamy, p. 21-52. In J. M. Black [ED.], Partnerships in birds: the study of monogamy. Oxford University Press, Oxford, England.

GRIFfith, S. C., I. P. F. Owens, AND K. A. Thuman. 2002. Extra pair paternity in birds: a review of interspecific variation and adaptive function. Molecular Ecology 11:2195-2212.

Haggerty, T. M., E. S. Morton, And R. C. Fleischer. 2001. Genetic monogamy in Carolina Wrens (Thryothorus ludovicianus). Auk 118:215-219.

HALL, M. L. 2004. A review of hypotheses for the functions of avian duetting. Behavioral Ecology and Sociobiology 55:415-430.

Hall, M. L. 2009. A review of vocal duetting in birds. Advances in the Study of Behavior 40:67-121.

Hall, M. L., and R. R. Magrath. 2000. Duetting and mateguarding in Australian Magpie-larks (Grallina cyanoleuca). Behavioral Ecology and Sociobiology 47:180-187.
Kingma, S. A., M. L. Hall, E. Arriero, And A. Peters. 2010. Multiple benefits of cooperative breeding in Purple-crowned Fairy-wrens: a consequence of fidelity? Journal of Animal Ecology 79:757-768.

Krueger, T. R., D. A. Williams, And W. A. Searcy. 2008. The genetic mating system of a tropical tanager. Condor 110:559-562.

Lawless, S. G., G. Ritchison, P. H. Klatt, and D. F. Westneat. 1997. The mating strategies of Eastern Screech-Owls: a genetic analysis. Condor 99:213-217.

Macedo, R. H., J. Karubian, And M. S. Webster. 2008. Extrapair paternity and sexual selection in socially monogamous birds: are tropical birds different? Auk 125:769-777.

Mann, N. I., K. A. Dingess, F. K. Barker, J. A. Graves, and P. J. B. SLATER. 2009. A comparative study of song form and duetting in neotropical Thryothorus wrens. Behaviour 146:1-43.

Masello, J. F., A. SRamkova, P. Quillfeldt, J. T. Epplen, and T. LubJuhn. 2002. Genetic monogamy in Burrowing Parrots Cyanoliseus patagonus? Journal of Avian Biology 33:99-103.

Melland, R. R. 2000. The genetic mating system and population structure of the Green-rumped Parrotlet. Ph.D. dissertation, University of North Dakota, Grand Forks, ND.

MenNiLl, D. J. 2006. Aggressive responses of male and female Rufous-and-white Wrens to stereo duet playback. Animal Behaviour 17:219-226.

Mennill, D. J., And S. L. Vehrencamp. 2005. Sex differences in the singing and duetting behavior of neotropical Rufous-and-white Wrens (Thryothorus rufalbus). Auk 122:175-186.

Mennill, D. J., And S. L. Vehrencamp. 2008. Context-dependent functions of avian duets revealed through microphone array recordings and multi-speaker playback. Current Biology 18:1314-1319.

Mennill, D. J., Ramsay, S. M., Boag, P. T., and Ratcliffe, L. M. 2004. Patterns of extrapair mating in relation to male dominance status and female nest placement in Black-capped Chickadees. Behavioral Ecology 15:757-765.

Moore, O. R., B. J. M. Stutchbury, and J. S. Quinn. 1999. Extrapair mating system of an asynchronously breeding tropical songbird: the Mangrove Swallow. Auk 116:1039-1046.

Morton, E. S., B. J. M. Stutchbury, J. S. Howlett, And W. H. PIPER. 1998. Genetic monogamy in Blue-headed Vireos and a comparison with a sympatric vireo with extrapair paternity. Behavioral Ecology 9:515-524.

Mulder, R. A., P. O. Dunn, R. A. Cockburn, K. A. LazenbyCoHen, AND M. J. Howell. 1994. Helpers liberate female fairywrens from constraints on extra-pair mate choice. Proceedings of the Royal Society of London B 255:223-229.

Osmun, A. E., AND D. J. Mennill. 2011. Congruent patterns of territoriality in male and female neotropical songbirds. Ethology 117:385-394.

Petren, K., B. R. Grant, and P. R. Grant. 1999. Low extrapair paternity in the Cactus Finch (Geospiza scandens). Auk 116:252-256.

Robertson, B. B. C. 1996. The mating system of the Capricorn Silvereye. Ph.D. dissertation, University of Queensland, St. Lucia, Brisbane, Australia.

Seutin, G., B. N. White, And P. T. Boag. 1991. Preservation of avian blood and tissue samples for DNA analysis. Canadian Journal of Zoology 69:82-90.

SonNenschein, E., AND U. REYER. 1983. Mate-guarding and other functions of antiphonal duets in the Slate-coloured Boubou (Lanarius funebris). Zeitschrift für Tierpsychologie 63:112-140.

Stutchbury, B. J., AND E. S. MorTon. 1995. The effect of breeding synchrony on extra-pair mating systems in songbirds. Behaviour 132:675-690. 
Stutchbury, B. J. M., And E. S. Morton. 2001. Behavioral ecology of tropical birds. Academic Press, San Diego.

Stutchbury, B. J. M., E. S. Morton, AND W. H. Piper. 1998. Extrapair mating system of a synchronously breeding tropical songbird. Journal of Avian Biology 29:72-78.

Stutchbury, B. J. M., E. S. MorTon, AND B. Woolfenden. 2007. Comparison of the mating systems and breeding behavior of a resident and a migratory tropical flycatcher. Journal of Field Ornithology 78:40-49.

Topp, S. M., AND D. J. Mennill. 2008. Seasonal variation in the duetting behaviour of Rufous-and-white Wrens (Thryothorus rufalbus). Behavioral Ecology and Sociobiology 62:1107-1117.

Tori, W. P., R. Durães, T. B. Ryder, M. Anciães, J. Karubian, R. H. Macedo, J. A. C. Uy, P. G. Parker, T. B. Smith, A. C. Stein, M. S. Webster, J. G Blake and, B. A Loiselle. 2008. Advances in sexual selection theory: insights from tropical avifauna. Ornitología Neotropical 19:151-163.
Verboven, N., and A. C. Mateman. 1997. Low frequency of extra-pair fertilizations in the Great Tit Parus major revealed by DNA fingerprinting. Journal of Avian Biology 28:231-239.

Weatherhead, P. J., and S. M. Yezerinac. 1998. Breeding synchrony and extra-pair mating in birds. Behavioral Ecology and Sociobiology 43:217-219.

Webster, M. S., C. W. Varian, and J. Karubian. 2008. Plumage color and reproduction in the Red-backed Fairy-wren: why be a dull breeder? Behavioral Ecology 19:517-524.

Westneat, D. F., AND I. R. K. SteWARt. 2003. Extra-pair paternity in birds: causes, correlates, and conflict. Annual Review of Ecology, Evolution, and Systematics 34:365-396.

WiCKLER, W. 1980. Vocal duetting and the pair bond. I. Coyness and partner commitment. A hypothesis. Zietschrift für Tierpsychologie 52:201-209. 